\title{
ICE THICKNESS AND BEDROCK ELEVATION IN WESTERN NEUSCHWABENLAND AND BERKNER ISLAND, ANTARCTICA
}

\author{
by \\ H. Hoppe and F. Thyssen \\ (Forschungsstelle für physikalische Glaziologie der Westfälischen Wilhelms-Universität, \\ Corrensstraße 24, D-4400 Münster, Federal Republic of Germany)
}

\section{ABSTRACT}

In 1985-86, western Neuschwabenland was surveyed with an electromagnetic reflection system (EMR) over flight tracks totalling $6100 \mathrm{~km}$. The area spans a triangle from Ekström Ice Shelf and Heimefront Range to the Kraul Mountains [Vestf jella] and covers $48000 \mathrm{~km}^{2}$.

Data on surface elevation, ice thickness and bedrock topography are presented in maps. The bedrock-elevation map shows more detail than earlier compilations, with a remarkable graben-like structure north of the Heimefront Range and large areas of bedrock below sea-level.

In the same season, tracks totalling $1600 \mathrm{~km}$ were flown over Berkner Island. High electromagnetic reflectivity was found over the southern part of Berkner Island, whereas the northern part showed considerably lower reflectivity. We believe that this is due to melting conditions in the southern part and freezing conditions in the northern part.

\section{INTRODUCTION}

In the 1985-86 season western Neuschwabenland and Berkner Island were surveyed by the German research aircraft Polar 2 along flight tracks totalling $7700 \mathrm{~km}$. During this survey, data on ice thickness, total magnetic field, radar altitude, pressure altitude and navigation were digitally recorded. Ice thickness was determined by an electromagnetic reflection system (EMR), using a mean frequency of $35 \mathrm{MHz}$ and a pulse width of $500 \mathrm{~ns}$. Four readings of ice thickness were recorded each second. The overall dynamic range of the system used is about $150 \mathrm{~dB}$.

Ice thickness can be determined directly from $75 \%$ of the data, without further digital signal processing. In the remaining $25 \%$, the bedrock-reflection signal is too weak to be detected in the field record, due to either: (a) small electromagnetic reflection coefficients at the ice-rock interface and/or (b) great ice thickness. Surface-elevation data are available for each position along the flight lines.

\section{WESTERN NEUSCHWABENLAND}

The bedrock-elevation map of western Neuschwabenland shows wide areas below sea-level (Fig. 1). The mountainous regions, namely the Kraul Mountains, Heimefront Range and Ritscher Upland, are left open, because insufficient data were collected to map their relatively complex topography. In addition to the mountain areas, a subglacial plateau more than $200 \mathrm{~m}$ a.s.1. connects Ritscher Upland with the Kraul Mountains. In the most easterly part of this plateau, a mountainous ice-covered region was discovered; it can be explained as a lateral spur of Borg Massif (not shown in Fig. 1). Two graben-like structures separated by a ridge more than $200 \mathrm{~m}$ a.s.l. are situated between this plateau and the Heimefront Range. The northern graben is about $40 \mathrm{~km}$ wide, with a bottom $200 \mathrm{~m}$ below sea-level and an east-west axis. The southern graben, which narrows to the east, follows the line of the Heimefront Range and steadily widens and shallows as it changes direction toward the southern part of Riiser-Larsen Ice Shelf. The northern and north-western boundary of the Heimefront Range is represented by this graben. North of the Heimefront Range, where the graben bottom lies more than $800 \mathrm{~m}$ below sea-level, the bedrock elevation changes more than $3000 \mathrm{~m}$ over a distance of $2 \mathrm{~km}$.

These grabens are situated within an important ice outlet of the Antarctic plateau. A cross-section of the area along $9^{\circ} \mathrm{W}$ is presented in Figure 3. The shaded area of this section is about $147 \mathrm{~km}^{2}$. Because we do not know the ice-flow velocity we cannot calculate the mass flux.

North and north-west of the Heimefront Range the bedrock-reflection signals are very weak. The bedrock elevation in this area is based on a compilation of reflection-seismic measurements (Hungeling and Thyssen, in press) and EMR flight lines. Seismic and EMR ice thicknesses at the crossing point of measurement lines differ by less than $\pm 20 \mathrm{~m}$. Measurements in the Heimefront Range (not shown in Fig. 1) show strong reflection signals even though the ice is more than $2000 \mathrm{~m}$ thick. A southern or south-eastern boundary of the mountainous Heimefront Range was not detected.

EMR records in non-mountainous regions generally show a smooth relief. Towards the ice front, bedrock elevation decreases slowly in the direction of Ekström Ice Shelf and more rapidly in the direction of Riiser-Larsen Ice Shelf. This corresponds to bathymetric measurements in front of these ice shelves (Hinz and Krause 1982).

D.J. Drewry and S.R. Jordan have compiled a bedrock-elevation map of Antarctica with $500 \mathrm{~m}$ contour intervals (Drewry 1983). The area shown in Figure 1 was covered by one flight line (dashed line in Fig. 1), connecting Halley Station (west of the mapped area), the Kraul Mountains, Heimefront Range and Lyddan Ice Rise (west of the mapped area). We could not find detailed information about these measurements. Additionally, seismic data from the Norwegian-British-Swedish Antarctic Expedition 1949-52 (Robin 1958) along the line connecting Quarisen, Ekström Ice Shelf and Borg Massif (east of the mapped area) were used. These ice thicknesses coincide with our results with one exception. At the north-western front of the Heimefront Range the bedrock elevations differ. Using EMR flight lines and seismic investigations (Hungeling and Thyssen, in press), we have located a graben-like structure with a bottom $600 \mathrm{~m}$ below sea-level at this position; the earlier measurements indicate an elevation $500 \mathrm{~m}$ above sea-level. The map presented here shows more detail because more bedrock-elevation data have become available.

The smooth surface elevation in this area (Fig. 2) is adequately represented by Drewry (1983). There are no differences larger than $100 \mathrm{~m}$ between the two surfaceelevation maps. Thus it is assumed that errors in altitude data are not the reason for the differences between the bedrock-elevation maps north of the Heimefront Range. 


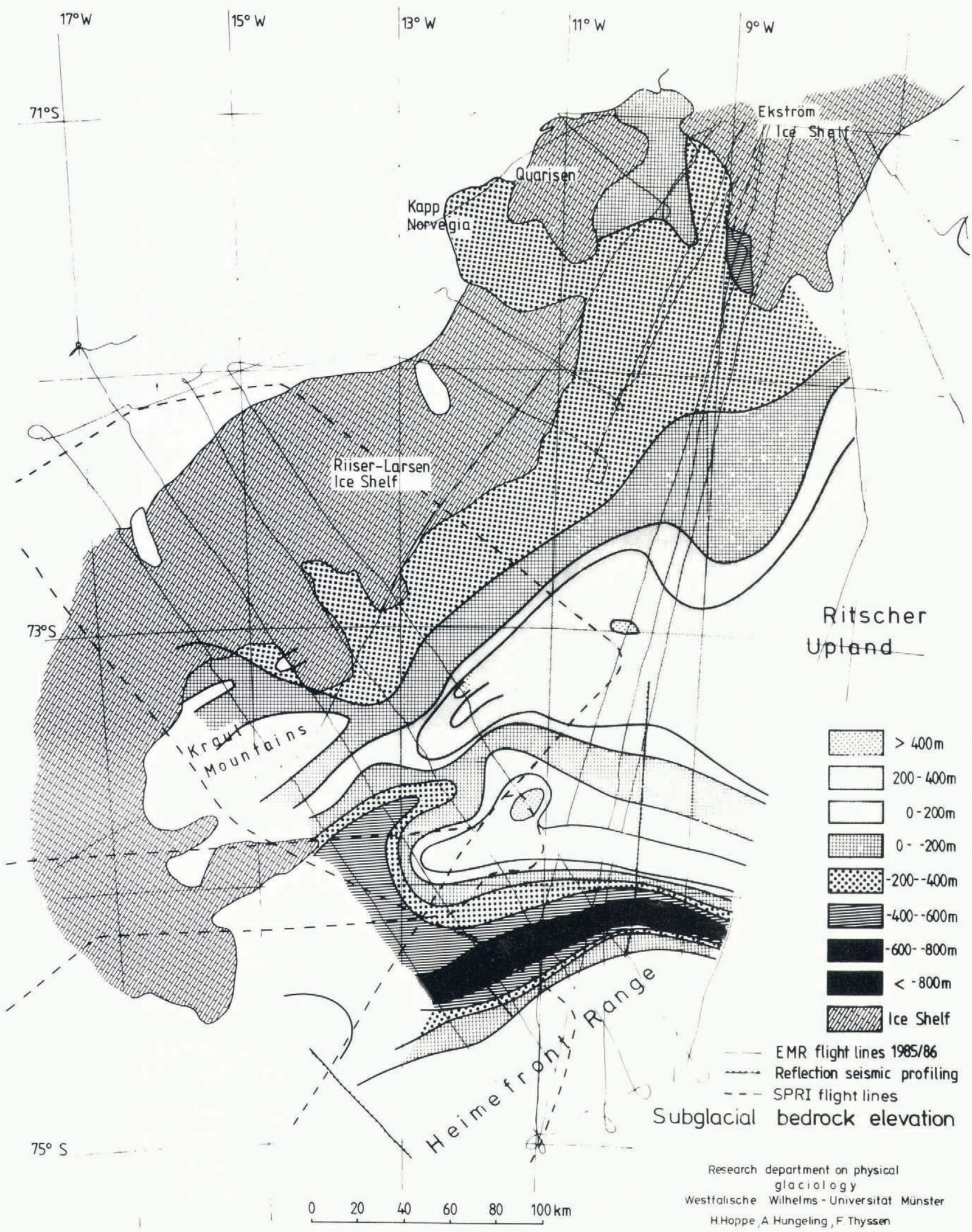

Fig. 1. Bedrock elevation in western Neuschwabenland, contour interval $200 \mathrm{~m}$. Ice front and grounding line based on Drewry (1983).

\section{BERKNER ISLAND}

Berkner Island was surveyed as part of the FilchnerRonne Ice Shelf Programme in 1985-86 along flight tracks totalling $1600 \mathrm{~km}$. From these data, contour maps of bedrock and surface elevation were produced (Figs 4 and
5). The most interesting evidence from the surface elevations is that Berkner Island is divided into two summit areas: a southern summit with a maximum elevation of $940 \mathrm{~m}$ and a northern summit with a maximum elevation of $730 \mathrm{~m}$. Maximum calculated ice thicknesses are $1100 \mathrm{~m}$ for the southern part and $940 \mathrm{~m}$ for the northern part. 


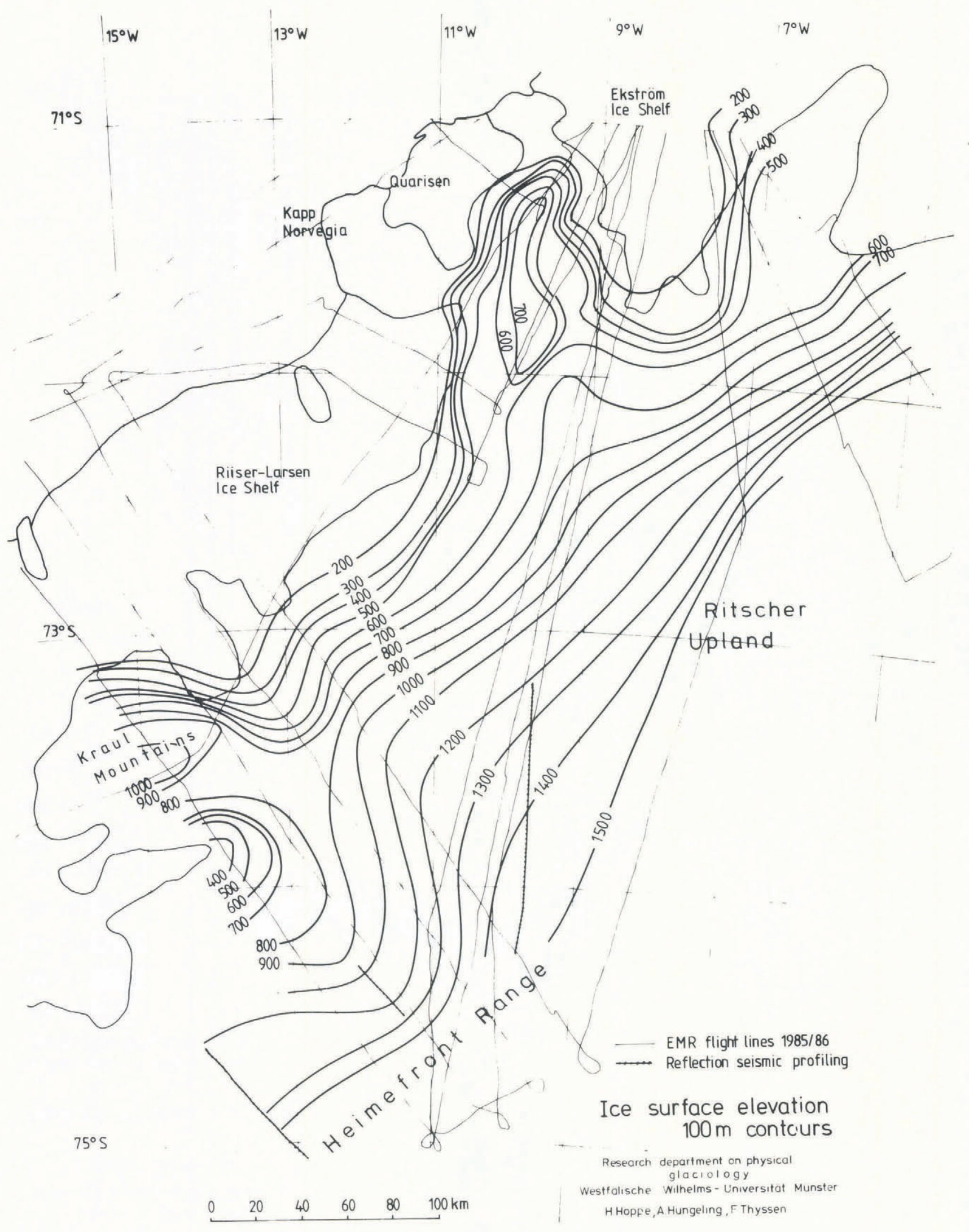

Fig. 2. Surface elevation in western Neuschwabenland, contour interval $100 \mathrm{~m}$. Ice front and grounding line based on Drewry (1983).

From Figures 4 and 5 it can be seen that bedrock and surface elevations increase slowly from west to east. There is no sharp step in ice thickness coming from Filchner Ice Shelf on to Berkner Island from the west. Coming from the south, the ice thickness decreases on reaching Berkner Island in a step of approximately $350 \mathrm{~m}$, equivalent to nearly half the ice thickness at the grounding line. At the eastern grounding line the ice thickness of $400-500 \mathrm{~m}$ increases quickly toward the west, without a rapid change at the grounding line. The same is true of bedrock and surface elevation.

For McCarthy Inlet a maximum ice thickness of more than $600 \mathrm{~m}$ was calculated. A deep canyon, more than $200 \mathrm{~m}$ below sea-level, $45 \mathrm{~km}$ long and about $10 \mathrm{~km}$ wide, 


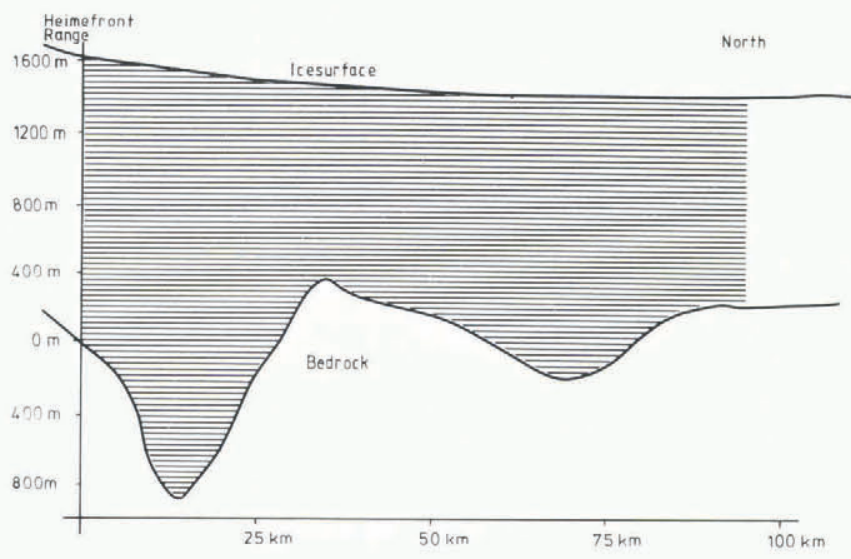

Fig. 3. Cross-section of bedrock and surface elevation along $9^{\circ} \mathrm{W}$, north of Heimef ront Range.

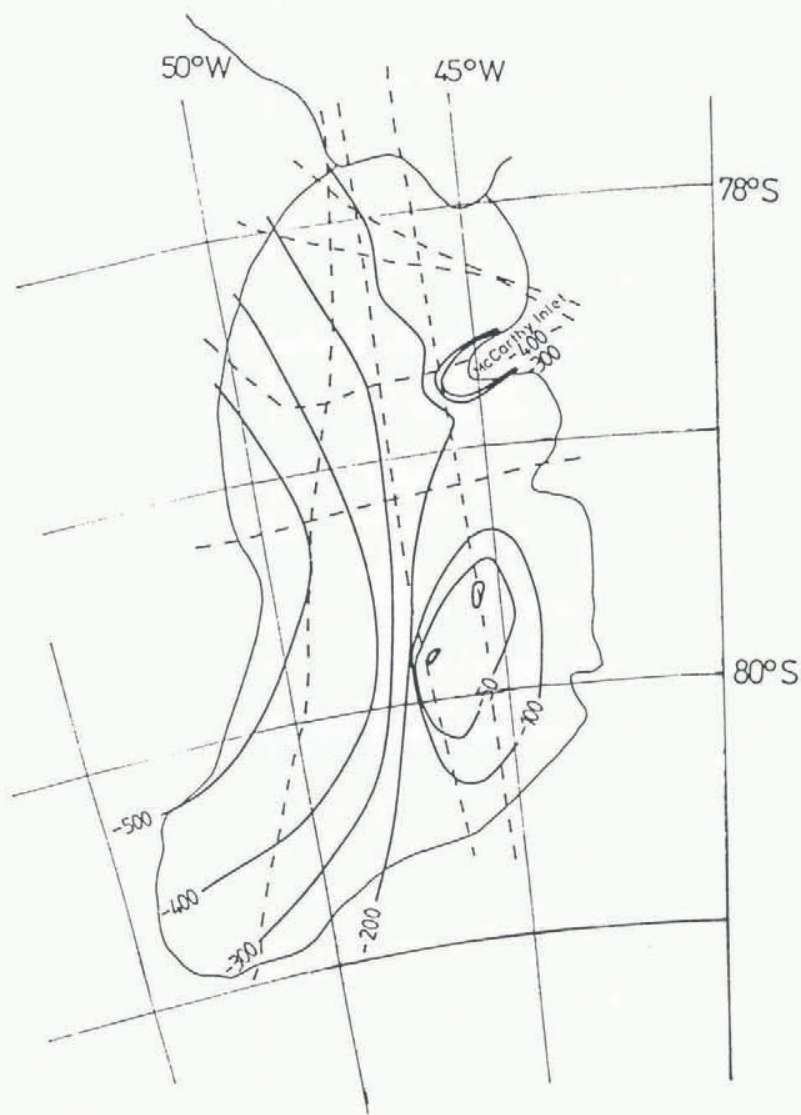

- - - -EMR flight lines $1985 / 86$

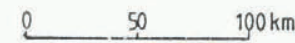

Fig. 4. Bedrock elevation on Berkner Island, contour interval $100 \mathrm{~m}$. Ice front and grounding line based on Drewry (1983).

was found below McCarthy Inlet. Although the bottom of the canyon was not detected, it lies at least $570 \mathrm{~m}$ below sea-level. This canyon divides the bedrock surface in the eastern part of the island into two separate areas: a small hill reaching sea-level in the south and a plateau $200 \mathrm{~m}$ below sea-level in the north. The bedrock elevation of Berkner Island as a whole rises from west to east.

The two areas show remarkably different electromagnetic bottom reflections that are independent of ice thickness: namely, strong bottom reflections in the southern part and weak bottom reflections in the northern part. These may be caused by surface conditions, bedrock conditions, conditions at the ice-rock interface, or internal layering. In the EMR records there is no evidence for a change in surface reflectivity or internal layering. The bedrock-elevation map (Fig. 4) shows a smooth surface except in McCarthy Inlet, with no morphological indication of different rock species. Recently published aeromagnetic investigations show no difference between the northern and

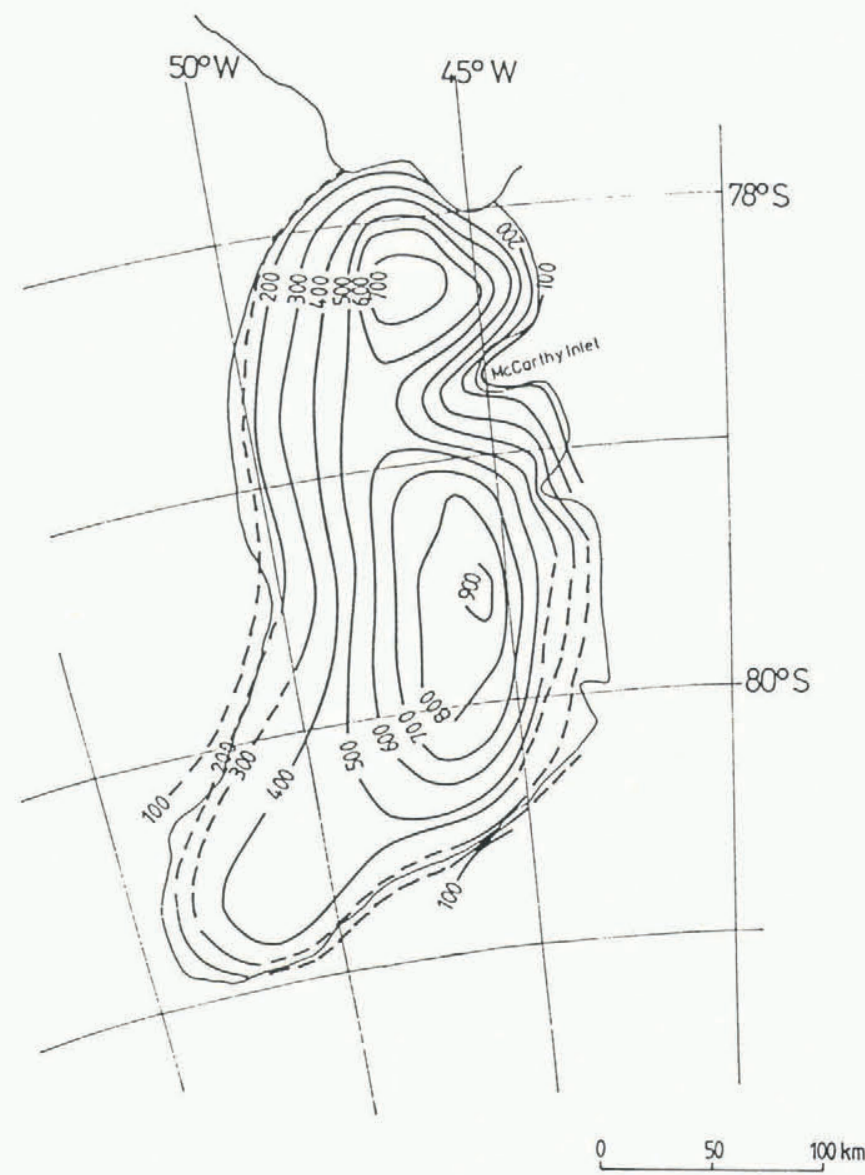

Fig. 5. Surface elevation on Berkner Island, contour interval $100 \mathrm{~m}$. Ice front and grounding line based on Drewry (1983).

southern parts of Berkner Island (Maslanyj and Garrett, in press). We believe there is no electromagnetic evidence for a change in bedrock geology.

Thus the difference in magnitude of electromagnetic reflections is probably caused by conditions at the ice-rock interface. The cause could be either melting in the southern part and freezing in the northern part, or a clean ice-bed contact in the southern part and a till layer in the northern part. Final conclusions may come from more detailed digital processing of the reflection data.

\section{ACKNOWLEDGEMENTS}

This work has been supported by the Bundesministerium für Forschung und Technologie, the Deutsche Forschungsgemeinschaft and the Ministerium für Wissenschaft und Forschung Nordrhein-Westfalen.

\section{REFERENCES}

Drewry, D.J., ed. 1983. Antarctica: glaciological and geophysical folio. Cambridge, University of Cambridge. Scott Polar Research Institute.

Hinz, K., and W. Krause. 1982. The continental margin of Queen Maud Land / Antarctica: seismic sequences, structural elements and geological development. Geol. Jahrb., Reihe E, 23.

Hungeling, A., and F. Thyssen. In press. Reflection seismic measurements in western Neuschwabenland. In Fifth International Symposium on Antarctic Earth Sciences, Cambridge 1987.

Maslanyj, M., and S.W. Garrett. In press. Aeromagnetic and gravity anomaly of West Antarctica. In Fifth International Symposium on Antarctic Earth Sciences, Cambridge 1987.

Robin, G. de Q. 1958. Glaciology III. Seismic shooting and related investigations. Norwegian-British-Swedish Antarctic Expedition, 1949-52. Scientific Results, 5. 